\title{
ASPEK GEOLOGI DIDALAM PENYUSUNAN WILAYAH USAHA PERTAMBANGAN MINERAL LOGAM
}

\author{
Oleh: \\ Ernowo dan Bambang Pardiarto \\ Pusat Sumber Daya Geologi \\ Jl. Soekarno Hatta No. 444 Bandung
}

\begin{abstract}
SARI
Undang-Undang Nomor 4 Tahun 2009 tentang Pertambangan Mineral dan Batubara mengamanatkan kepada pemerintah untuk menetapkan Wilayah Pertambangan (WP) sebagai bagian dari Tata Ruang Nasional. Wilayah yang bisa diterbitkan perijinannya ditetapkan oleh pemerintah terlebih dahulu berupa WUP untuk kemudian dilakukan pelelangan kepada para pelaku usaha pertambangan dalam bentuk Wilayah Izin Usaha Pertambangan (WIUP).

Beberapa kriteria Wilayah Usaha Pertambangan (WUP) mineral logam yang berkaitan dengan geologi sebagaimana ditetapkan didalam Peraturan Pemerintah nomor 22 Tahun 2010 tentang Wilayah Pertambangan adalah memiliki formasi batuan pembawa mineral logam, memiliki singkapan geologi untuk mineral logam, memiliki potensi sumber daya mineral dan memiliki satu atau lebih jenis mineral termasuk mineral ikutannya. Penyusunan WUP tidak bisa dipisahkan dengan Wilayah Pencadangan Negara (WPN) dimana memiliki kesamaan didalam kriteria-kriteria geologi.

Penerapan konsep geologi dan keterdapatan mineral sangat diperlukan didalam penyusunan WUP/WPN dimana disusun berdasar data yang sifatnya masih umum (regional) berupa litologi, stratigrafi dan struktur geologi. Keterkaitan WIUP yang akan dilelang dengan tahapan kegiatan eksplorasi tergantung dari tingkat penyelidikan didalam penyediaan data tersebut.
\end{abstract}

Kata Kunci; WUP, WPN, geologi

\section{ABSTRACT}

Law no 4/ 2009 regarding Mineral and Coal Mining mandates the government to set a mining zone (WP) as part of the National Land Use. Areas that may be issued permissions set by the government as WUP then conducted the auction to the mining investors as Mining Permits Area (WIUP).

Some criteria of WUP associated with the geosciences as stipulated in Government Regulation no. 22/2010 regarding WP are mineral hosted formations, has a geologic outcrop to metallic minerals, have the potential mineral resources and has one or more minerals. WUP formation can not be separated with national resource area (WPN) which have the same criteria in the geosciences.

Application of the geology and mineralization concept in the preparation of the WUP / WPN where by compiling general data of lithology, stratigraphy and structural geology. WIUP in therms of phases of exploration depends on the level of investigation in the provision of such data.

Keywords: WUP, WPN, geology.

\section{PENDAHULUAN}

Kebijakan pemerintah didalam pengelolaan sumberdaya mineral saat ini mengacu kepada Undang-Undang Nomor 4 Tahun 2009 tentang Pertambangan Mineral dan Batubara (UU Minerba). UU Minerba tersebut mengamanatkan kepada

pemerintah untuk menetapkan Wilayah Pertambangan (WP) sebagai bagian dari Tata Ruang Nasional. Wilayah Pertambangan terdiri dari Wilayah Usaha Pertambangan (WUP), Wilayah Pencadangan Negara (WPN) dan Wilayah 
Pertambangan Rakyat (WPR).

Di dalam peraturan perundangundangan sebelumnya izin kegiatan eksplorasi diterbitkan berdasar pengajuan lokasi oleh pemohon. Saat ini wilayah yang bisa diterbitkan perizinannya ditetapkan oleh pemerintah terlebih dahulu berupa WUP untuk kemudian dilakukan pelelangan kepada para pelaku usaha pertambangan dalam bentuk Wilayah Izin Usaha Pertambangan (WIUP) untuk komoditi mineral logam dan/atau batubara. Sehingga pemerintah dituntut untuk menyediakan wilayah yang layak ditawarkan kepada pelaku usaha pertambangan untuk dilakukan kegiatan eksplorasi.

Tulisan ini memuat pemahaman penulis mengenai peraturan yang ada serta mencoba mengaplikasikan konsep konsep geologi dan mineralisasi didalam penentuan WUP untuk komoditi mineral logam dengan tujuan memberikan masukan didalam penyusunannya.

\section{WILAYAH USAHA PERTAMBANGAN}

Didalam UU Minerba disebutkan bahwa WUP merupakan bagian dari WP yang memiliki ketersediaan data, potensi dan/atau informasi geologi. Satu WUP terdiri atas satu atau beberapa (WIUP) yang berada pada lintas wilayah provinsi, lintas wilayah kabupaten/kota, dan/atau dalam satu wilayah kabupaten/kota. Luas WIUP mineral logam paling sedikit 5.000 hektar dan paling banyak 100.000 hektar. Peraturan Pemerintah no 23 Tahun 2010 Tentang Pelaksanaan Kegiatan Usaha Pertambangan Mineral dan Batubara menyebutkan bahwasanya WIUP mineral logam atau batubara dapat diperoleh dengan cara lelang. Sebagai dasar untuk melaksanakan kegiatan eksplorasi maka didalam WIUP yang sudah dilakukan pelelangan tersebut diterbitkan ljin Usaha Pertambangan (IUP) Eksplorasi (Gambar 1).

Mengacu kepada Peraturan Pemerintah No 22 Tahun 2010 tentang Wilayah Pertambangan pasal 20, kriteria didalam penyusunan WUP komoditi mineral logam adalah : memiliki formasi batuan pembawa mineral logam termasuk wilayah lepas pantai berdasarkan peta geologi, memiliki singkapan geologi untuk mineral logam, memiliki potensi sumber daya mineral, memiliki satu atau lebih jenis mineral termasuk mineral ikutannya, tidak tumpang tindih dengan WPR dan/atau WPN, merupakan wilayah yang dapat dimanfaatkan untuk kegiatan pertambangan secara bekelanjutan dan merupakan kawasan peruntukan pertambangan sesuai dengan rencana tata ruang.

Penyusunan WUP tidak bisa dipisahkan dengan WPN dimana memiliki kesamaan didalam kriterianya sesuai PP. No 22 Tahun 2010 pasal 29 yaitu; memiliki formasi batuan pembawa mineral logam termasuk wilayah lepas pantai berdasarkan peta geologi, memiliki singkapan geologi untuk mineral logam berdasar data/peta geologi, memiliki potensi/cadangan mineral logam ditambah kriteria untuk keperluan konservasi komoditas tambang, berada pada wilayah dan/atau pulau yang berbatasan dengan negara lain, merupakan wilayah yang dilindungi; dan/atau berada pada pulau kecil dengan luas maksimal $2.000 \mathrm{~km}^{2}$ sesuai dengan ketentuan peraturan perundang-

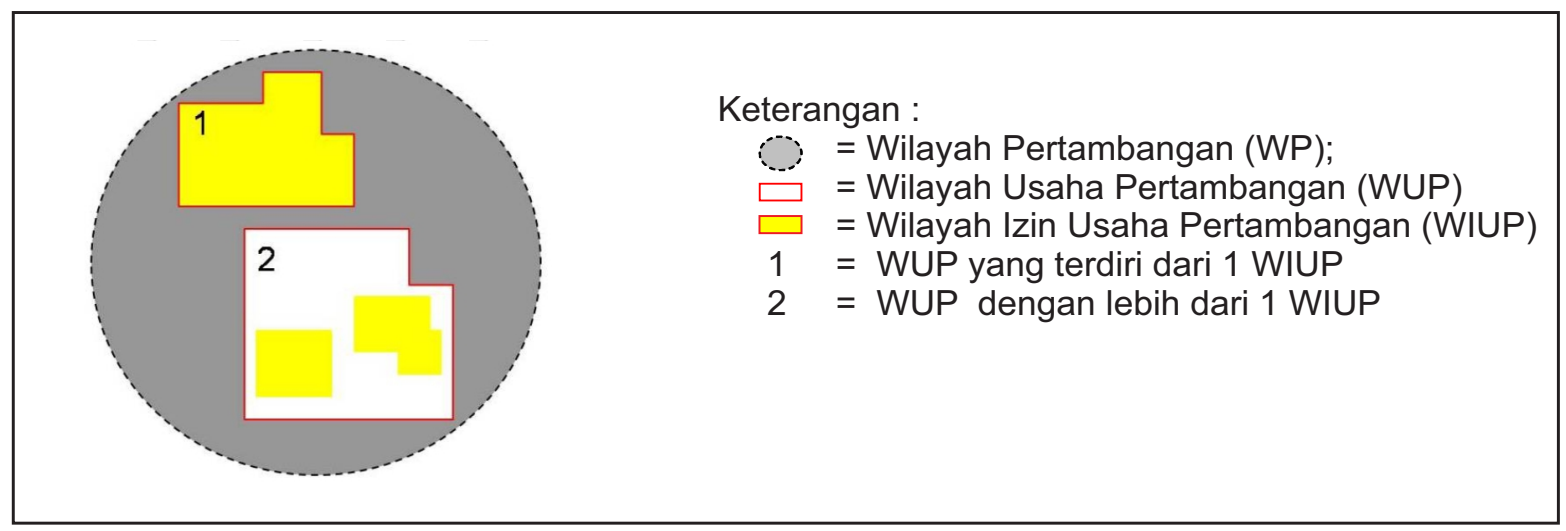

Gambar 1. Skema hubungan antara WP, WUP dan WIUP. 
undangan.

Sesuai dengan PP No 22 tahun 2010 pasal 5, data yang dipergunakan didalam penyusunan WUP/WPN merupakan data yang diinvetarisasi pemerintah hasil penyelidikan oleh pemerintah pusat, pemerintah daerah maupun perusahaan yang berupa data geologi hasil evaluasi dari kegiatan pertambangan yang sedang berlangsung, telah berakhir, dan/atau telah dikembalikan kepada menteri, gubernur, atau bupati/walikota sesuai dengan kewenangannya.

\section{GEOLOGI DAN KETERDAPATAN MINERAL LOGAM DI INDONESIA}

Busur Kepulauan Indonesia yang terletak diantara dua Paparan Benua Asia dan Australia sudah sejak lama menjadi perhatian para ahli geologi dan pertambangan. Hal yang menarik dari keadaan geologi Indonesia yaitu terdapatnya zona jalur magmatik berumur Permo-Karbon hingga Tersier yang menempati kepulauan Indonesia bagian barat dan adanya jalur gunungapi serta palung-palung laut dalam yang membujur dari bagian barat Sumatera, bagian selatan Jawa, Nusa Tenggara, Maluku, Sulawesi dan berlanjut ke Filipina. Secara regional Indonesia terletak pada daerah tumbukan tiga lempeng besar, yakni Lempeng Benua Eurasia, Lempeng Benua India-Australia dan Lempeng Samudra Pasifik yang mengakibatkan kondisi struktur geologi yang kompleks dan kandungan variasi energi dan mineral seperti : minyak dan gasbumi, batubara, gambut, panas bumi, tembaga, emas, nikel, timah serta mineralmineral lainnya.

Cebakan mineral logam di Indonesia yang meliputi emas, perak, tembaga, seng, timbal, timah, besi, nikel, mangan, aluminium, dll., terletak pada jalur magmatik pembawa mineralisasi seperti Jalur SundaBanda, Jalur Kalimantan-Tengah, Jalur Sulawesi Timur-Mindanau, Jalur Halmahera dan Jalur Irian Jaya Tengah (Gambar 2 ).

Secara keseluruhan terdapat 15 jalur magmatik yang terbentuk di sepanjang kepulauan Indonesia dengan panjang

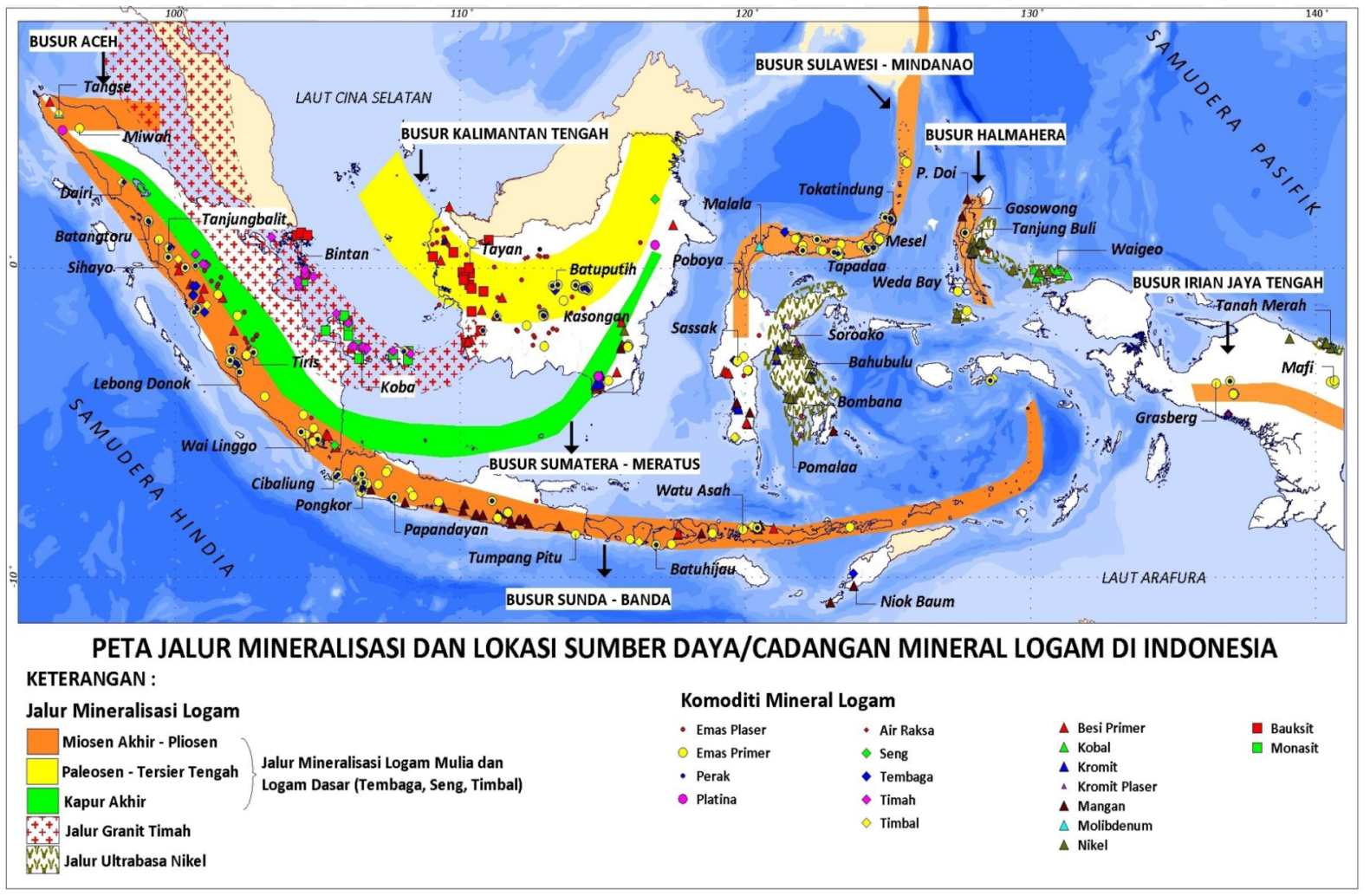

Gambar 2. Peta jalur mineralisasi dan lokasi mineral logam (Modifikasi Carlile,J.C and Mitchell, A.H.G. 1994) 
mencapai lebih dari $15.000 \mathrm{~km}$ (Carlile dan Mitchell, 1994). Selain membentuk jalur magmatik proses tektonik memunculkan batuan kerak samudera berkomposisi ultrabasa di beberapa tempat di bagian timur Indonesia. Jalur magmatik pembawa mineralisasi logam tersebut secara geologi dibentuk oleh aneka ragam batuan yang terdiri dari umumnya batuan gunungapi, terobosan batuan beku, batuan sedimen dan sebagian kecil batuan ofiolit. Keragaman komoditi dan tipe mineralisasi logam dipengaruhi formasi atau jenis batuan baik batuan pembawa maupun batuan samping. Guilbert \& Park (1986) membuat klasifikasi keterdapatan jenis mineralisasi berdasarkan asosiasi batuannya yang diantaranya meliputi batuan beku, batuan vulkanik, batuan sedimen, kerak benua dan batuan metamorf.

\section{PEMBAHASAN}

Peran geologi didalam penyusunan WUP/WPN adalah menerapkan konsep pembentukan dan pengendapan mineral dengan data-data geologi yang merupakan kriteria WUP. Data yang dipakai berupa Peta Geologi lembar Sindangbarang dan Bandarwaru skala 1 : 250.000 (M. Koesmono, Kusnama \& N. Suwarna, 1996) terbitan Pusat Penelitian dan Pengembangan Geologi yang merupakan data geologi regional bersistem ditunjang dengan data keterdapatan mineral logam baik indikasi maupun sumberdaya. Berdasarkan beberapa kriteria geologi meliputi stratigrafi, litologi dan struktur geologi dapat dideliniasi WUP/WPN.

\section{STRATIGRAFI}

Jika mineral logam diketahui terbentuk didalam litologi tertentu atau dengan kata lain pada horizon stratigrafi, maka langkah pertama untuk menentukan lokasi prospek adalah menentukan indikasi permukaan dan memperluas pada horizon yang sama. Contoh endapan mineral yang dipengaruhi kondisi stratigrafi adalah pasir besi (Gambar 3) dan endapan-endapan tipe placer lainnya. Endapan pantai di selatan Jawa Barat terindikasi memiliki kandungan pasir besi pada beberapa lokasi. Endapan tersebut merupakan akumulasi hasil transport oleh sungai-sungai yang membawa rombakan material-material mengandung bijih besi dari batuan-batuan gunungapi di bagian utara baik Formasi Jampang maupun endapan piroklastika tak terpisahkan yang memiliki komposisi andesitik. Penyebaran endapan pantai tersebut atas dasar kesamaan stratigrafi dan indikasi keterdapatan pasir besi diusulkan sebagai blok WUP.

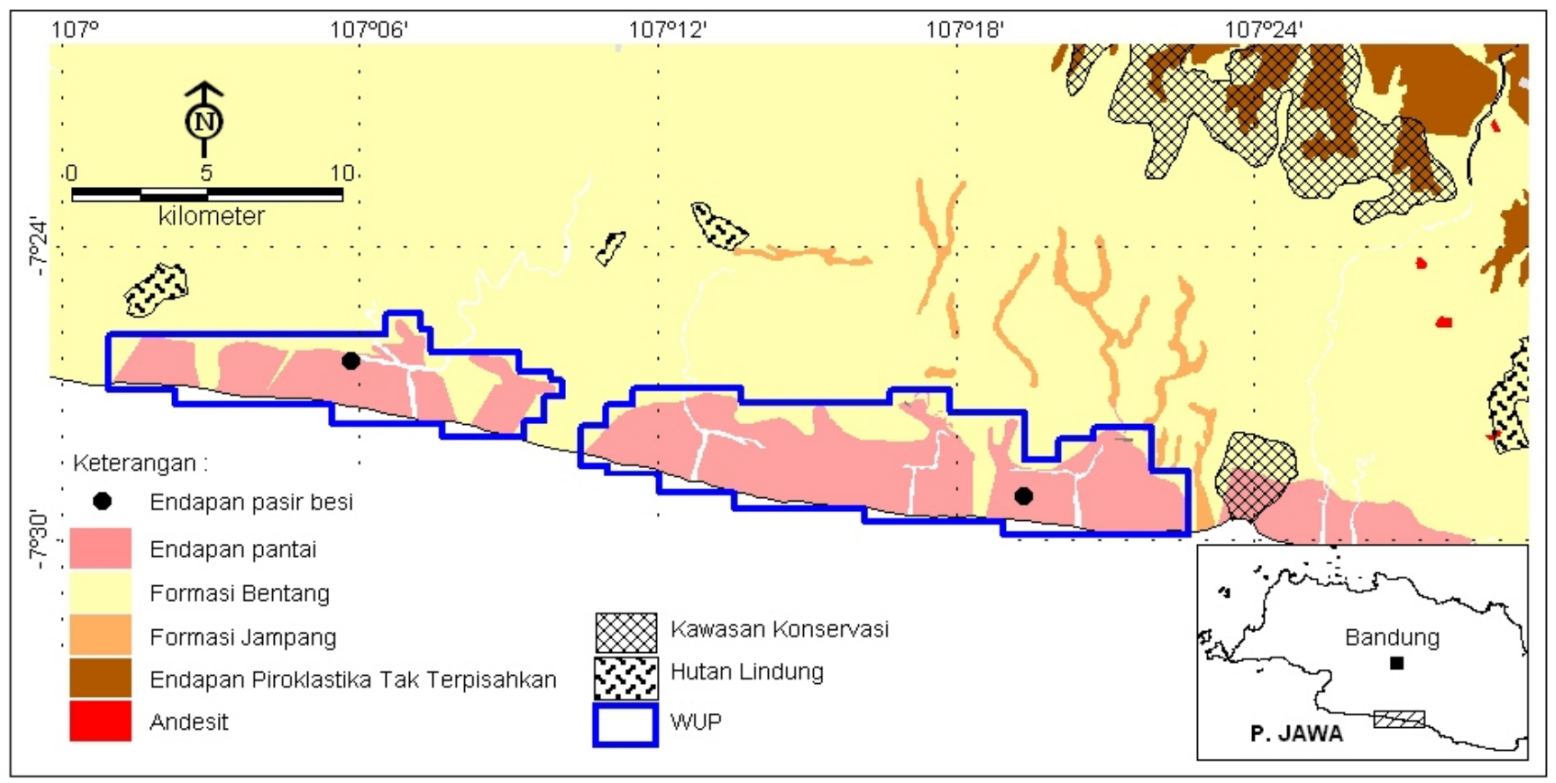

Gambar 3. WUP pasir besi didukung kriteria stratigrafi (Geologi modifikasi dari Koesmono, 1996) 


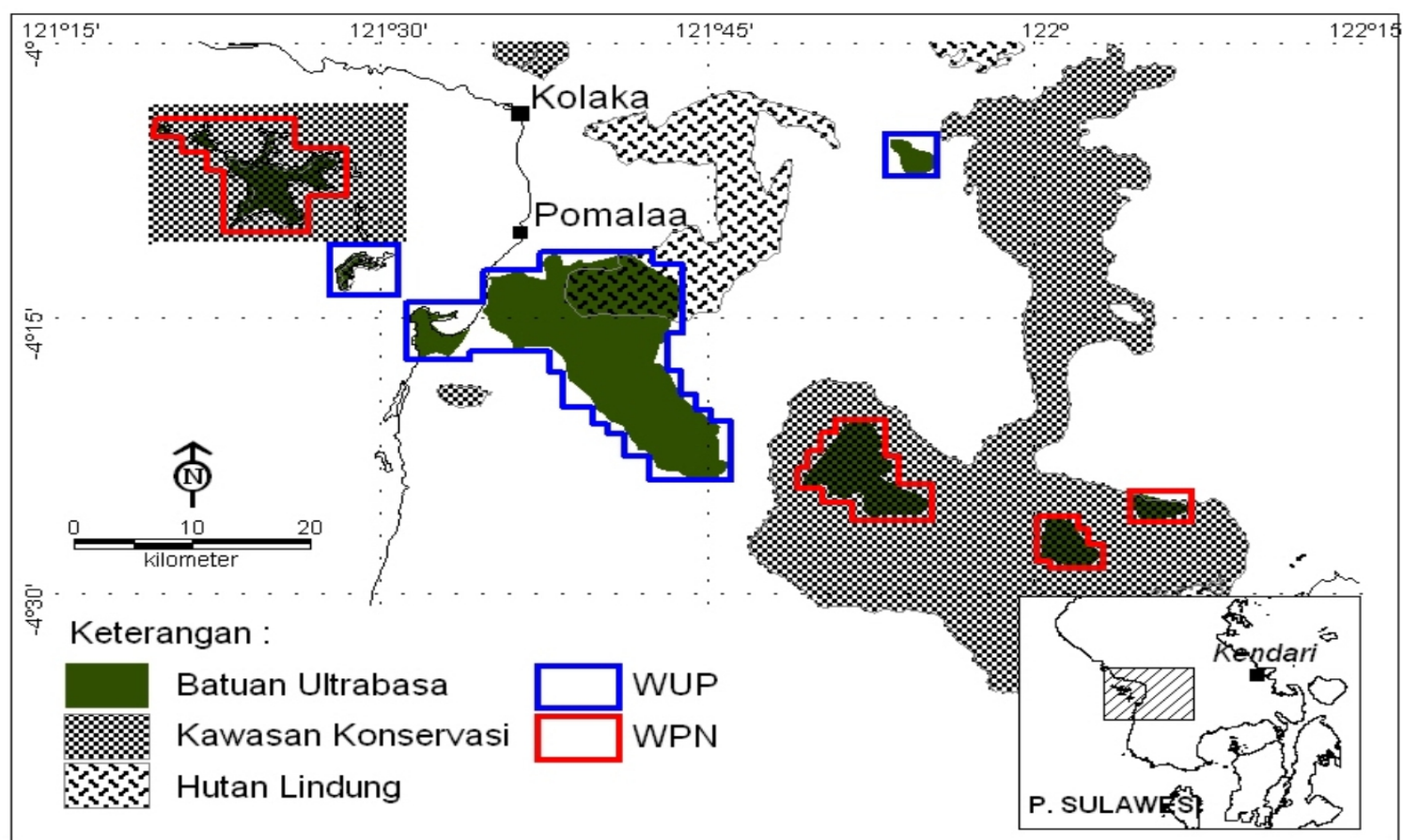

Gambar 4. WUP dan WPN nikel ditentukan oleh litologi ultrabasa (Geologi modifikasi dari Simanjuntak dkk, 1993)

\section{LITOLOGI}

Jenis litologi yang bisa langsung diusulkan untuk WUP/WPN salah satunya adalah batuan ultrabasa (Gambar 4). Endapan mineral yang pada batuan ultrabasa adalah nikel dengan mineral mineral penyerta berupa kobalt, kromit dan besi. Hal ini terjadi karena ada proses pelapukan pada batuan ultrabasa. Pelapukan akan memencarkan satu atau beberapa unsur sehingga terjadi pengayaan unsur-unsur tersebut (Guilbert \& Park, 1986). Endapan ini dikenal sebagai nikel laterit. Usulan blok WUP dideliniasi pada daerah yang berimpit dengan hutan lindung, sedangkan WPN yang berimpit dengan kawasan konservasi.

Beberapa contoh jenis litologi lain (Gambar 5) yang memiliki sifat akomodatif terhadap proses mineralisasi selain batuan ultrabasa di daerah Sulawesi bagian selatan adalah batuan gunungapi, batuan terobosan intermediet-asam dan batuan terobosan basa. Cebakan tipe epitermal dan cebakan tipe kuroko dapat terbentuk pada batuan gunung api, cebakan logam dasar tipe porfiri pada batuan intrusi intermediet-asam dan cebakan kromit-platinum pada intrusi batuan ultrabasa (Guilbert\&Park, 1986)

\section{STRUKTUR GEOLOGI}

Struktur geologi merupakan faktor pengontrol didalam proses mineralisasi logam. Beberapa cebakan mineral terbentuk pada daerah yang diterobos oleh batuan intrusi. Struktur yang terbentuk sebelum mineralisasi merupakan struktur terpenting karena berfungsi sebagai saluran larutan bijih dan bisa terbentuk mineral. Sedangkan struktur yang terbentuk setelah mineralisasi akan merubah geometri mineral bijih.

Kombinasi antara stratigrafi, litologi dan struktur geologi menjadi faktor penting didalam pembentukan mineralisasi. Sedangkan daerah prospek ditentukan oleh adanya batuan samping yang memiliki komposisi material gunungapi dengan struktur geologi berupa sesar yang relatif intensif dan diterobos oleh batuan beku sebagai pembawa larutan hidrotermal. Kondisi daerah seperti ini memiliki peluang akan terbentuknya cebakan logam primer. Sehingga daerah tersebut dimasukkan kedalam WUP, sementara yang didalam 


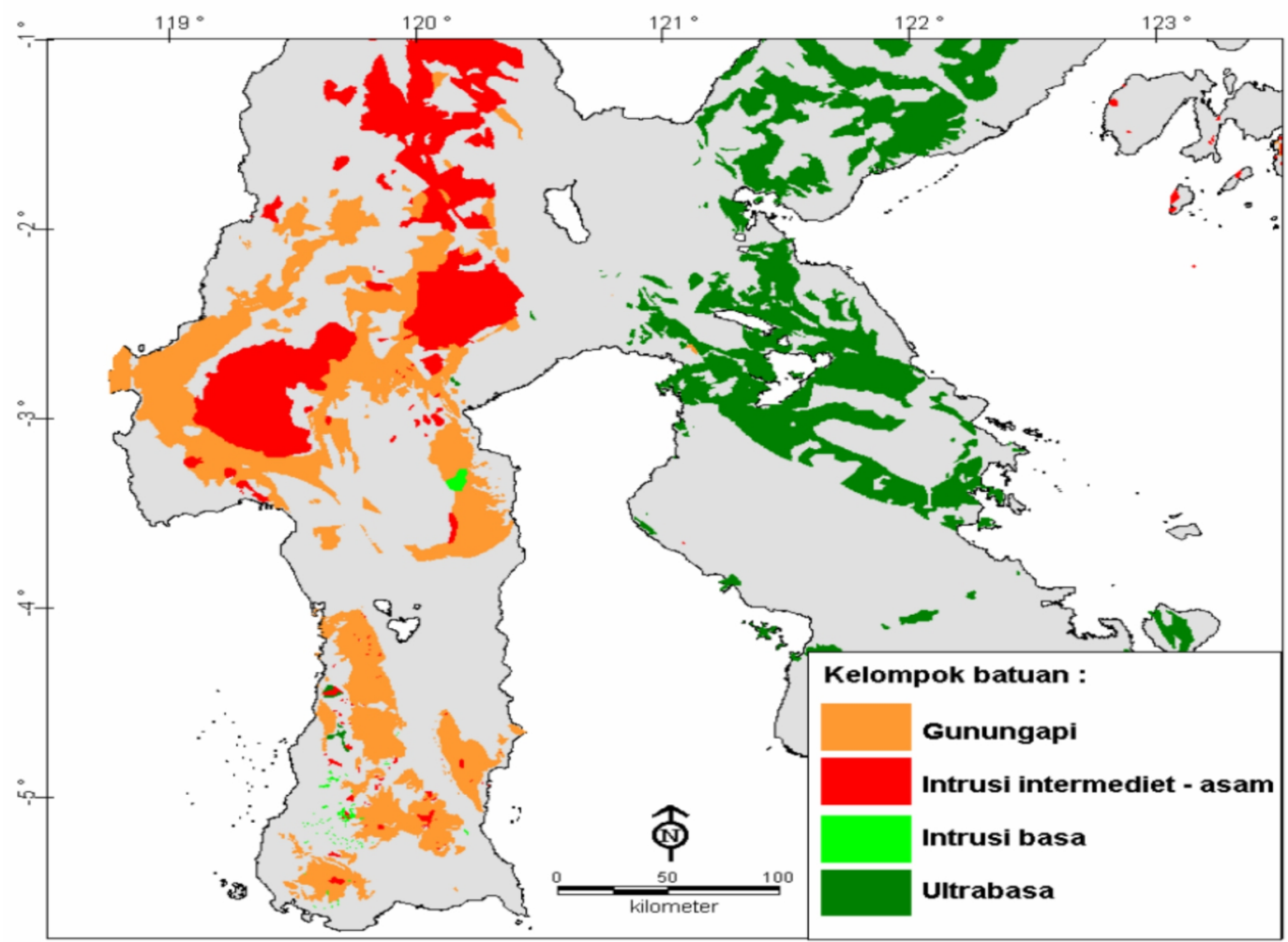

Gambar 5. Kelompok batuan di Sulawesi bagian selatan sebagai pembawa mineral logam (Modifikasi dari berbagai peta geologi daerah Sulawesi bagian selatan terbitan Pusat Penelitian dan Pengembangan Geologi)

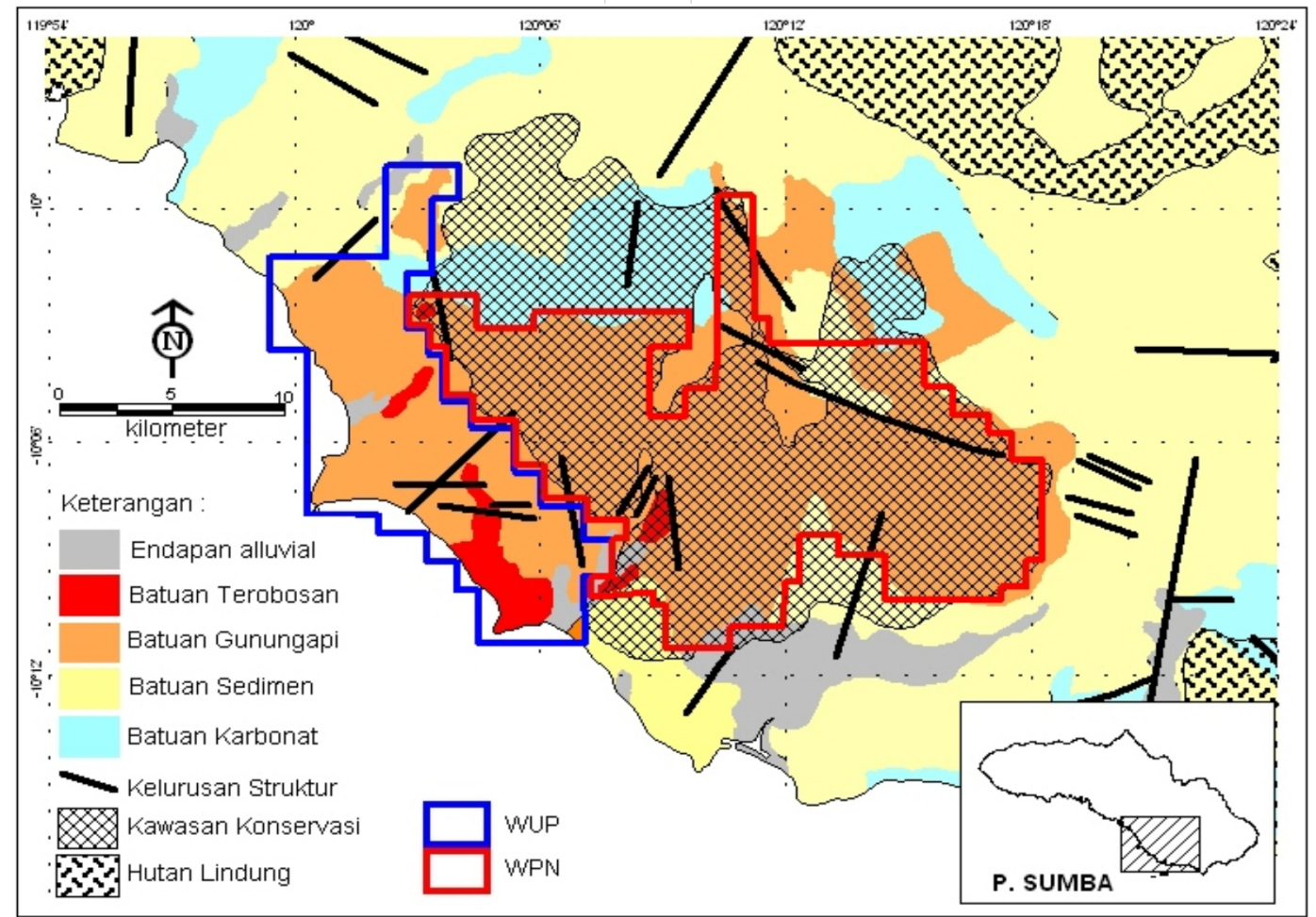

Gambar 6. Tampilan peta WUP dan WPN mineral logam yang dikontrol oleh faktor stratigrafi, litologi dan struktur geologi. (Geologi modifikasi dari Affendi \& Apandi, 1993) 
Tabel Hubungan tahapan eksplorasi, WIUP dan ketersediaan data

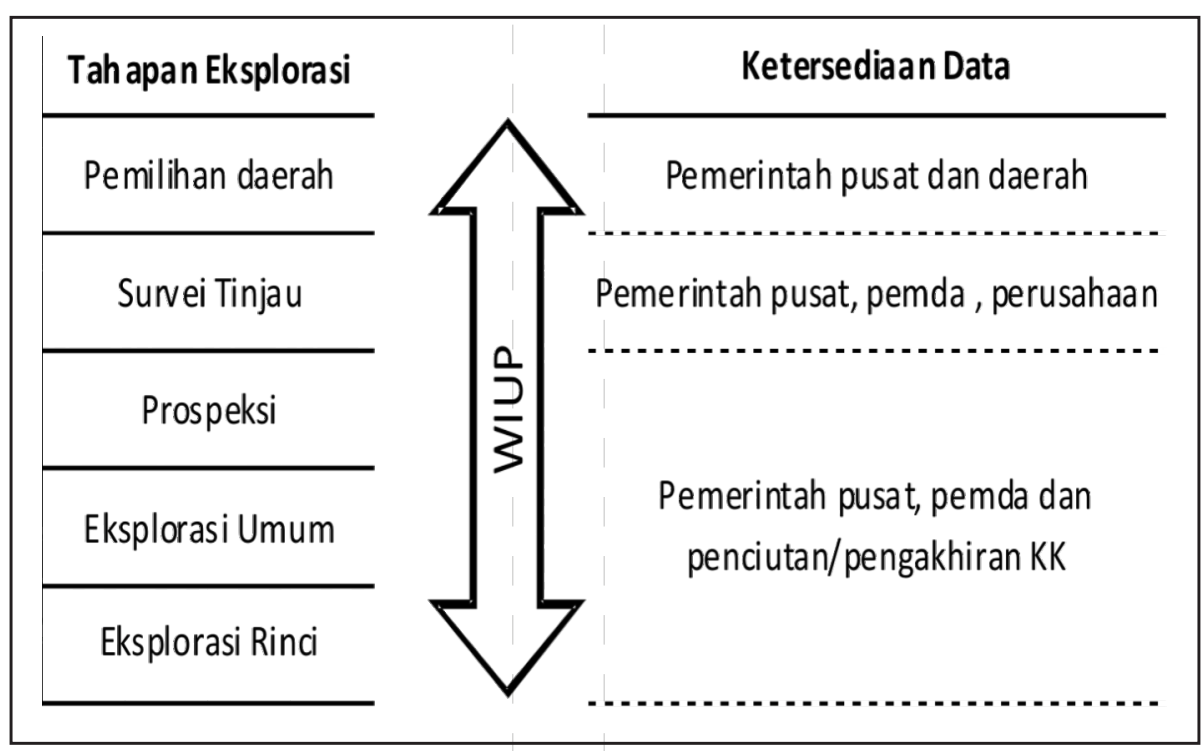

Apabila dikaitkan dengan tahapan kegiatan eksplorasi maka WIUP yang akan dilelang bisa berada pada semua tahapan tergantung kepada kelengkapan data yang dipakai didalam penyusunannya. (Tabel). Untuk data pemilihan area, survey tinjau dan prospeksi banyak tersedia dari hasil penyelidikan oleh pemerintah pusat, pemerintah daerah dan perusahaan. Data eksplorasi umum dan eksplorasi rinci selain menggunakan hasil penelitian pemerintah pusat dan daerah, sebagian besar bisa diambil dari data penciutan dan pengakhiran Kontrak Karya.

\section{KESIMPULAN}

WUP dan WPN disusun berdasar kriteria teknis yang sama, dimana WPN bisa ditetapkan untuk kepentingan strategis nasional sebagai daerah yang dicadangkan untuk komoditas tertentu dan daerah konservasi untuk menjaga keseimbangan ekosistem dan lingkungan. Data yang dipergunakan merupakan hasil inventarisasi oleh pemerintah terhadap hasil-hasil penelitian oleh pemerintah pusat, pemerintah daerah dan perusahaan.

Aplikasi geologi berupa penerapan konsep geologi dan keterdapatan mineral sangat diperlukan didalam penyusunan WUP/WPN dimana disusun berdasar data yang sifatnya masih umum (regional) maupun data-data detail hasil kegiatan eksplorasi baik oleh pemerintah maupun perusahaan.

Keterkaitan WIUP yang ditawarkan untuk dilelang dengan tahapan kegiatan eksplorasi tergantung dari tingkat penyelidikan didalam penyediaan data tersebut. WIUP yang sudah ditetapkan dan dilelang menjadi tugas pemegang IUP untuk menindaklanjuti dengan kegiatan eksplorasi selanjutnya.

\section{DAFTAR PUSTAKA}

Affendi A.C dan Apandi T, 1993, Peta Geologi Lembar Waikabubak dan Waingapu, Sumba, PPPG, Bandung.

Carlile,J.C and Mitchell, A.H.G. 1994. Magmatic arcs and associated gold and copper mineralization in Indonesia. Journal of Geochemical Exploration 50. Elsevier, hal. 91-142.

Djuri \& Sudjatmiko, 1974, Peta Geologi Lembar Majene dan Bagian Barat Palopo, PPPG, Bandung.

Guilbert, J.M., and Park, C.F., 1986, The Geology of Ore Deposits, W.H.Freeman \& Company.

Koesmono M, Kusnama \& N. Suwarna, 1996, Peta Geologi Lembar Sindangbarang dan Bandarwaru, Jawa Barat, PPPG, Bandung.

Kuzvart,M dan Bohmer,M, 1986, Prospecting And Exploration Of Mineral Deposits, Elsevier. 
Rab Sukamto, 1982, Peta Geologi Lembar Pangkajene dan Bagian Barat Watampone, PPPG, Bandung. Rab Sukamto \& Supriatna S., 1982, Peta Geologi Lembar Ujung Pandang, Benteng dan Sinjai, PPPG, Bandung.

Ratman N, Atmawinata S., 1993, Peta Geologi Lembar Mamuju, PPPG, Bandung.

Rusmana E, Sukido, Haryono E, Simanjuntak T.O., 1993, Peta Geologi Lembar Lasusua-Kendari, PPPG, Bandung.

Sikumbang N., Sanyoto P., Supandjono J.B., Gafoer S., 1995, Peta Geologi Lembar Buton, PPPG, Bandung.

Simanjuntak T.O, Surono, Sukidom, 1993, Peta Geologi Lembar Kolaka, Sulawesi, PPPG, Bandung

Simanjuntak T.O., Surono, Supandjono J.B., 1991, Peta Geologi Lembar Poso, PPPG, Bandung.

Simandjuntak T.O., Rusmana E, Surono., Supandjono J.B., 2007, Peta Geologi Lembar Malili, PPPG, Bandung.

Simanjuntak T.O, E. Rusmana, Supandjono J.B., 1993, Peta Geologi Lembar Bungku, PPPG, Bandung.

Sukido, Sukarna D, Sutisna K., 1993, Peta Geologi Lembar Pasangkayu, PPPG, Bandung.

Surono, Simanjuntak T.O., Situmorang R.L., Sukido, 1993, Peta Geologi Lembar Batui, PPPG, Bandung. Undang Undang No 4 Tahun 1999 tentang Pertambangan Mineral dan Batubara.

Peraturan Pemerintah No 22 Tahun 2010 tentang Wilayah Pertambangan.

Peraturan Pemerintah No 23 Tahun 2010 tentang Pelaksanaan Kegiatan Usaha Pertambangan Mineral dan Batubara. 